\title{
СОЦИАЛЬНО-ЭКОНОМИЧЕСКОЕ ЗНАЧЕНИЕ КРУПНЫХ ГОРОДОВ В УСЛОВИЯХ ГЛОБАЛИЗАЦИИ
}

\author{
(C) 2020 Петров Антон Маркович \\ кандидат экономических наук, доцент \\ ведущий научный сотрудник, Научно-исследовательский институт развития образования \\ Российский экономический университет имени Г.В. Плеханова, Россия, Москва \\ E-mail:PETROV-AM2000@yandex.ru \\ (C) 2020 Маяков Дмитрий Михайлович \\ главный специалист, Научно-исследовательский институт развития образования \\ Российский экономический университет имени Г.В. Плеханова, Россия, Москва \\ E-mail: Mayakov.DM@rea.ru
}

В статье кратко рассматриваются основные черты крупных городов, а также их проблемы в глобальном контексте. Авторами рассматриваются особенности, преимущества и проблемы крупных городов в современных условиях, а также раскрывается роль глобальных городов в контексте международных отношений. Глобальные города стали поставщиками международных услуг. Кроме того, в статье указывается, что решения проблем развития крупных городов должно иметь комплексный характер.

Ключевые слова: города, мегаполисы, устойчивое развитие, глобализация, урбанизация, экономика, население, рейтинг, Москва.

Современные исследователи, с одной стороны, рассматривают процесс формирования и развития городов в неразрывной связи с процессами урбанизации. С другой стороны, города рассматриваются как самостоятельные феномены, обладающие особенностями и внутренней логикой поступательного развития. Город не только совокупность различных взаимосвязанных и взаимодополняющих компонентов (инфраструктурного, архитектурного, производственного, экономического и т.п. характера), которые обеспечивают условия для жизнедеятельности людей, но и совокупность положительных и отрицательных черт, накопленных за весь период развития человеческого общества. Отдельный город и каждый отдельный горожанин находятся в неразрывной связи общественных отношений, которые детерминированы как особенностями исторического развития, так и глобальными факторами. И, наконец, город подвержен постоянным трансформациям, качественным изменениям, которые определяют внутреннюю и внешнюю среду [9, С. 15, 19].

По данным ООН сейчас почти $56 \%$ населения мира проживает в городах. В соответствии с существующими прогнозами к 2030 году 60\% населения стран мира будет приходиться на городское население, а к 2050 году уже свыше 68\% [7].

В начале XXI века в мире имелось более полтысячи городов, население которых перевалило за 1 млн. человек. К 2030 году ожидается, что таких городов станет больше, примерно на 150. Следует отметить, что города, в которых проживает более 10 млн. человек, принято относить к мегаполисам (в 2016 году к мегаполисам в мире можно отнести 31 город). К 2030 году, по прогнозом, их может увеличиться до 41 города. Сейчас существует сорок пять городов с населением между 5 и 10 млн. человек (к 2030 году число городов, в которых будет насчитываться такое количество проживающих в них людей, составит 63 города). Отмечается также, что к 2030 году приблизительно 10 из городов с населением между 5 и 10 млн. человек станут мегаполисами [3].

В Российской Федерации, по данным Росстата, имеется 15 городов с численностью населения более 1 млн. человек (см. таблицу 1). Из них только 1 город с числом населения более 10 млн. человек - г. Москва (город федерального значения). Следом за столицей России идет г. СанктПетербург, с численностью населения свыше 5 млн. чел. [13].

Отметим, что г. Москва является не только столицей и крупным мегаполисом России, но и одним из глобальных городов, влияющих на международные отношения, в том числе и 
Таблица 1. Города РФ с численностью населения более 1 млн. чел. (по состоянию на 1 января 2019 г.)

\begin{tabular}{|c|l|c|c|l|c|}
\hline № & $\begin{array}{c}\text { Наименование города } \\
\text { РФ }\end{array}$ & Тыс. человек & № & $\begin{array}{c}\text { Наименование города } \\
\text { РФ }\end{array}$ & Тыс. человек \\
\hline 1. & г. Москва & 12615,3 & 9. & г. Самара & 1156,6 \\
\hline 2. & г. Санкт-Петербург & 5383,9 & 10. & г. Ростов-на-Дону & 1133,3 \\
\hline 3. & г. Новосибирск & 1618,0 & 11. & г. Уфа & 1124,2 \\
\hline 4. & г. Екатеринбург & 1483,1 & 12. & г. Красноярск & 1095,3 \\
\hline 5. & г. Нижний Новгород & 1253,5 & 13. & г. Воронеж & 1054,1 \\
\hline 6. & г. Казань & 1251,9 & 14. & г. Пермь & 1053,9 \\
\hline 7. & г. Челябинск & 1200,7 & 15. & г. Волгоград & 1013,5 \\
\hline 8. & г. Омск & 1164,8 & & & \\
\hline
\end{tabular}

на мировые экономические процессы. Москва имеет по многим параметрам своего развития высокий удельный вес в общероссийских основных экономических показателях (см. рисунок 1), а также в настоящее время характеризуется хорошими показателями в ряде международных рейтингов городов.

Значение глобальных городов в современном глобальном мире можно оценить как очень важное, так как они стали главными экономическими, научно-производственными площадками постиндустриального общества. Глобальные города со своей спецификой, особенностями устройства незаменимы для транснациональ- ных корпораций (ТНК), поскольку имеют возможности предложить данным корпоративным структурам комплекс сложных высокопрофессиональных услуг, в том числе финансового характера, а также коммуникаций с минимальными затратами на них.

В настоящее время глобальные города образуют на мировой экономической карте сеть, т.е. сейчас речь идет не просто об отдельных глобальных городах, а об их сети: «В действительности, организационная составляющая современной глобальной экономики представляет собой сеть из примерно сорока больших и малых глобальных городов, в которых она размещается

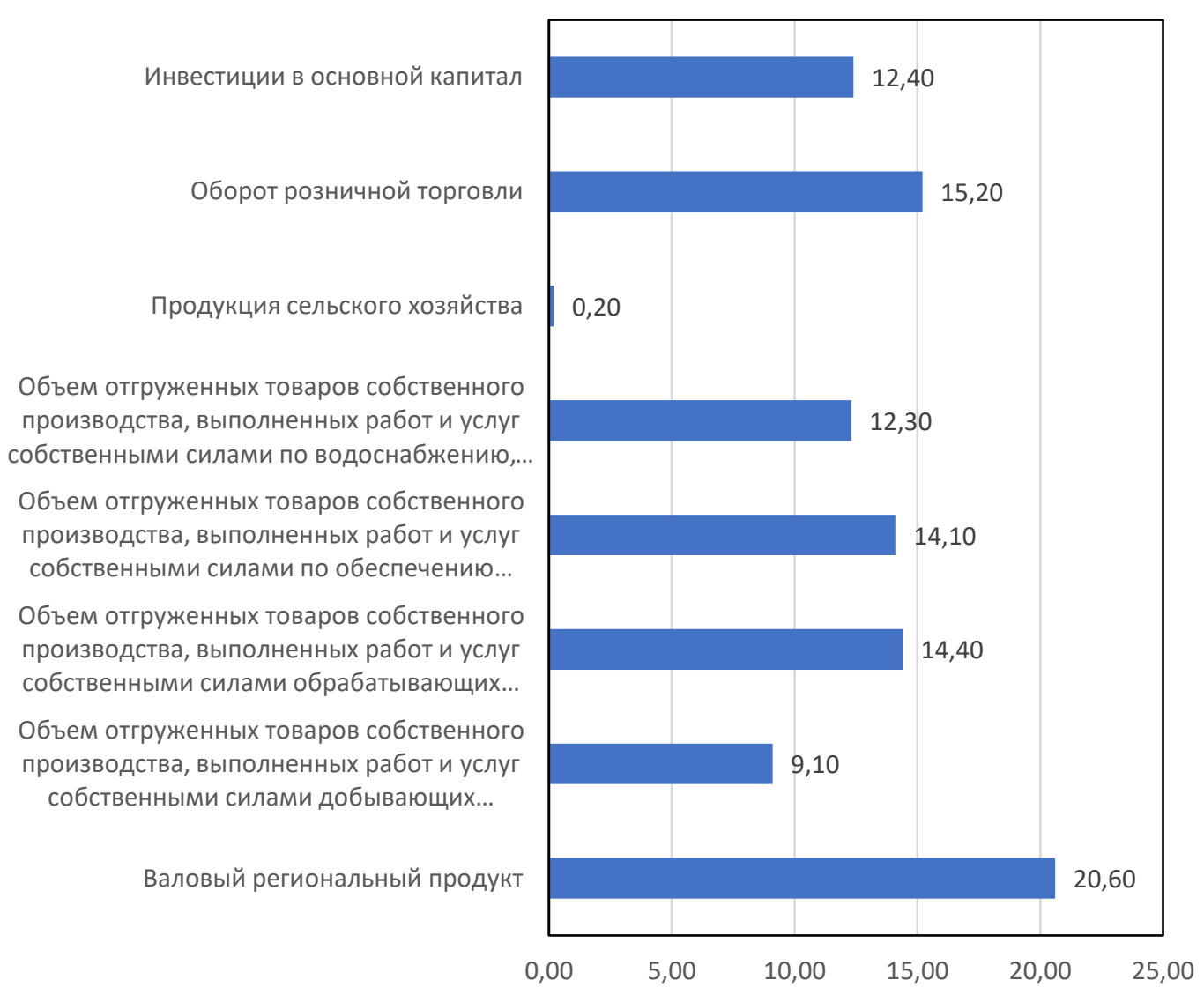

Puc. 1. Удельный вес города в общероссийских основных экономических показателях, \% [11] 
и постоянно обновляется» [16, С. 281]. При этом очевиден тот факт, что экономические судьбы глобальных городов всё меньше степени зависят от их национальных экономик. В транснациональных урбанистических сетях крупнейшие деловые центры приобретают особое значение, но в этих системах нет такого понятия, как отдельный глобальный город [1, С. 28].

Мегаполисы, особенно глобальные города, становятся местами привлечения и аккумуляции крупных международных финансовых ресурсов, реализации инвестиционных проектов, в том числе в строительно-архитектурной сфере, размещения представительств, штаб-квартир для крупных национальных компаний и транснациональных корпораций. Отмечается, что серьезным подспорьем экономической выгоде агломерации от осуществления деятельности ТНК на его территории является развитие системы корпоративной социальной ответственности. Глобальные города определяют международный уровень деловой активности (интенсивность коммуникационного взаимодействия мировых элит, возможности по формированию международных групп интересов и групп давления на основе отраслевых интересов), динамику международных потоков инвестиционного капитала, эволюцию мирового сообщества и его составных частей. Самые большие агломерации (глобальные города) развитого мира (Нью-Йорк, Лондон, Париж и Токио) представляют собой экономические центры развития макрорегионов (Северной Америки, Западной Европы) и государства Японии [8. C35, 36].

Нью-Йорк, Лондон, Токио, по мнению С. Сассен, являются площадками для «международных рынков ведущих представителей сферы услуг нашего времени, концентрации иностранных фирм и производителей, работающих на мировых рынках, а также они являются ключевыми площадками для международного рынка недвижимости». Данные характеристики таких городов обусловливают приобретение ими «глобального» статуса, и, как следствие, формирование системы глобальных городов [2, С. 50].

Таким образом, несмотря на всеобъемлющий пространственный охват, современный глобальный мир представляется городской цивилизацией. Большие города, особенно мегаполисы, формируют кристаллическую решетку глобального сообщества, они взаимодействуют, объединяются и образуют нервную систему со- временной глобальной экономики, доминирующую в бизнесе, торговле, предпринимательстве [14, С. 47-48].

Следует отметить, что за всю историю города накопили массу проблем: от хаотичного развития - до всевозможного загрязнения; от поселкового характера жизни до каменных джунглей, где не бывает солнца; от застройки набережных - до их периодического затопления. Кроме того, происходила трансформация городских агломераций: от городов-садов - до «садов на крыше»; от редких школ и гимназий - до университетов и всеобщего образования, в том числе и высшего [5, С. 11].

В свою очередь, мегаполисы, в том числе имеющих глобальный статус для мирового сообщества, стали инициаторами и центрами комплексного развития секторов рыночных и нерыночных интеллектуальных услуг (научные разработки, услуги в сфере информационных технологий, услуги в сферах профессионального консультирования) и высококачественных социальных услуг (образование, здравоохранение). Вложения в повышение качества жизни в городах, комфортности городской среды и жилищных условий, возможностей образования, с одной стороны, и повышение мобильности населения - с другой, позволяют привлечь в мегаполисы все большее число людей, в том числе значительные квалифицированные трудовые ресурсы, создать условия для инновационной деятельности и развития тех секторов современной городской экономики, которые способствуют (и будут способствовать) продуцированию наибольшего качественного экономического роста [14].

Неудивительно, что одной из наиболее популярных концепций городского развития в настоящее время стала концепция «умного» города, которая неразрывно связана с современными коммуникационными и информационными технологиями, энергосбережением, и как следствие, заботой об окружающей среде [1, С. 28, 29].

Проблема дефицита территории в процессе развития крупных городов также является актуальной для всего мирового сообщества [12, С. 145]. В настоящее время существует достаточно много соответствующих методик, которые напрямую или косвенно учитывают эффективность использования территорий города [4, С. 22].

Интерес к развитию крупных городов, глобальных мегаполисов со стороны общества, вла- 
сти, корпораций, средств массовой коммуникации привело к возникновению большого числа различных рейтингов городов мира, оценивающих их позиции в целом и/или по отдельным компонентам на международной арене. Ряд авторов сомневается в достоверности результатов таких рейтингов, но применение результатов рейтинговых инструментов стало широко применяемым в мире, в том числе городскими органами управления для оценки успешности мегаполисов и их вовлеченности в глобальную конкурентоспособность [15].

Отметим, к примеру, что г. Москва по последним результатам рейтинга Best Cities международной консалтинговой компании Resonance Consultancy вошла в пятерку лучших городов мира. Всего в рейтинге оценивалось 100 городов мира. Москву опередили только следующие мегаполисы: Лондон, Нью-Йорк, Париж и Токио. В ходе составления данного рейтинга эксперты оценивают города по шести критериям: «Место» (безопасность, городская среда), «Времяпрепровождение» (культура, ресторанная сфера и шопинг), «Продвижение» (упоминаемость в интернете), «Продукт» (инфраструктура, достопримечательности, конференц-возможности, работа аэропортов), «Люди» (процент жителей, переехавших в город из других государств, уровень образования) и «Экономическое процветание» (экономические показатели развития, количество штаб-квартир крупнейших компаний мира). При формировании рейтинга специалисты учитывают не только статистическую информацию, но и мнения, которыми в социальных сетях делятся местные жители и туристы [6]. Москва входит и в другие ведущие рейтинге (в топ-5 наиболее привлекательных для инвесторов европейских городов (Рейтинг Financial Times. 2018), 14 место из 128 городов в рейтин- ге международной консалтинговой компании (A. T. Kearney: Global Cities Index. 2018), 167 место из 231 по уровню качества жизни в рейтинге международной компании Mercer (Quality of Living Index.2018)) [10]. Сегодня руководство городом стремится улучшить позиции Москвы в данных и иных рейтингах городов мира, чтобы обеспечить конкурентоспособность мегаполиса на международной арене и использовать в политике продвижения имиджа города в мировом информационном пространстве.

Таким образом, крупные города, особенно имеющие «глобальный» статус, играют значительную социальную и экономическую роль для национальных хозяйственных систем (это финансово-экономические центры, центры высококачественного предоставления образовательных, медицинских и иных услуг, аккумуляции трудовой деятельности высококвалифицированных специалистов и т.п.), а также для мирового сообщества (глобальные города и их сети, обеспечивающие (а в большинстве случаях задающие направления мировым тенденциям) международные финансовые, торговые, деловые, научно-производственные и иные глобальные процессы). Различные рейтинги городов мира можно рассматривать в качестве одного из способов анализа влияния того или иного города на глобальном уровне. Москва, как один из ведущих мегаполисов мира, входит в ряд таких рейтингов, занимая достойные позиции в них. Однако, руководство Москвы, деловая элита города, как и любого другого мегаполиса мира, стремятся улучшить позиции города в международных рейтингах, для чего соответствующим управленческим структурам во взаимодействии со всеми заинтересованными сторонами необходимо предпринимать активные системные и комплексные подходы в данном направлении.

\section{Библиографический список}

1. Вершинина И.А., Добринская Д.Е. Рах urbanica: города в условиях глобальной сетевой цивилизации // Информационное общество. 2018. № 1. С. 25-33.

2. Грибова К. Города в XXI веке: сравнительный анализ теоретических подходов Саскии Сассен и Парага Ханны // Журнал социологии и социальной антропологии. 2018. 21(4). С. 38-62.

3. Города в 2016 году [Электронный ресурс]: Доклад ООН.- Режим доступа: https:/riss.ru/demography/ demography-analitycs/33499/]

4. Катенев В.В., Комаров А.Г. Проблемы размещения промышленных предприятий в мегаполисе // Экономические науки. 2016. № 143. С. 20-22.

5. Крушлинский В.И. Город, природа и общество. Проблемы взаимодействия: монография.-Красноярск: СФУ, 2017.- 166 c. 
6. Москва вошла в пятерку лучших городов мира [Электронный ресурс]: Новости.- Режим доступа: https:// www.mos.ru/news/item/67954073/ и https:/buyingbusinesstravel.com.ru/news/travel-management/40651moskva-voshla-v-pyaterku-luchshikh-gorodov-mira/

7. Население мира растет, стареет и переезжает в города [The world's population is growing, aging and moving to cities]. [Электронный ресурс]: Аналитическая информация ООН (1 апреля 2019 г.). - Режим доступа: https:// news.un.org/ru/story/2019/04/1352171

8. Попов Д.Г., Жабенко И.Д. Глобальный город как центр глобальных услуг // Научно-технические ведомости СПбГПУ. Гуманитарные и общественные науки. 2018. Т. 9. № 3. С. 28-38.

9. Пономарева М.А. История одного города: от глобальных изменений до повседневных практик // Новое прошлое. 2017. № 3. С. 10-24.

10. Рейтинги Москвы [Электронный ресурс].- Режим доступа: https://www.mos.ru/city/projects/awards/ratings/

11. Регионы России. Основные характеристики субъектов Российской Федерации, 2018 [Электронный ресурс]: Статистический сборник Федеральной службы государственной статистики.- Режим доступа: http://gks. $\mathrm{ru} / \mathrm{bgd} / \mathrm{regl} / \mathrm{b} 18 \_14 \mathrm{~s} /$.

12. Федорова В.А., Сафина Г.Р. Мировой и российский опыт решения территориальных проблем городов // Успехи современного естествознания. 2017. № 11. С. 141-145.

13. Численность населения Российской Федерации по муниципальным образованиям на 1 января 2019 года [Электронный ресурс]: Статистический сборник Федеральной службы государственной статистики.- Режим доступа: https://www.gks.ru/storage/mediabank/mun_obr2019.rar

14. Экономическая урбанизация / Н.Б. Косарева, Т.Д. Полиди, А.С. Пузанов - Москва: Фонд «Институт экономики города», 2018-418 с.

15. Ershova S, Orlovskaya T. Comparative Researches on strategic priorities of Russian megalopolises and global cities. In: International Multi-Conference on Industrial Engineering and Modern technologies. IOP Publishing IOP Conf. Series: Materials Science and Engineering. 2018 (463). 032037.

16. Sassen S. Seeing like a city / Burdett R., Sudjic D. (eds.) The Endless City. The Urban Age Project by the London School of Economics and Deutsche Bank’s Alfred Herrhausen Society. Phaidon Press Ltd, L.. NY. 2007. p. 281. 